\title{
Social Media and Prosumerism
}

\author{
Nicole A. Buzzetto-More \\ University Maryland Eastern Shore, Princess Anne, MD, USA
}

\author{
Nabuzzetto-More@umes.edu
}

\begin{abstract}
Pervasive mobile technologies, combined with the ease of access to multiple communication networks, have globalized communication exchanges in a way that is unprecedented. Compelled to receive constant information updates from their ever expanding peer networks, the average person has been transformed to a hyper-connected habitué of social media. Permanently tethered to their electronic devices they traverse the social media landscape seeking engagement and enlightenment all the while being exposed to a multitude of product and brand messages. As such, the new consumer is informed, self-motivated, and impelled by the opinions of others. Seizing the now unbridled opportunity to affect the attitudes of peers, many social customers serve as prosumers who act as influencing agents that propagate highly salient information about products and services via social channels.

In order to examine use and perceptions of social media, impact on customer relationship management, and overall effectiveness of different marketing strategies employed via social platforms, a nationwide survey of over 1,000 business practitioners was conducted. According to the findings most participants have made a purchase decision based on information they gathered through social media as social networking site (SNS) users influence others by actively promoting products and services. Social media adoption was found to be a strategic imperative for contemporary companies that can, if used expeditiously, support customer relationship management efforts; however, corporate professionals are not adequately informed with the strategies for effective use of social media to support marketing and brand management efforts. Finally, when message type was considered word of mouth messages were recognized as having the greatest salience.
\end{abstract}

Keywords: Social Customer Relationship Management, CRM, Social Networking, Social Marketing, Word of Mouth Marketing, Prosumer, Social Customer, Interactive Marketing, Message Salience, Word of Mouth Messaging, Social Media Messages

\section{Literature Review}

Social networking sites have emerged as a vital information resource used by individuals for product and brand information (Silver,

Material published as part of this publication, either on-line or in print, is copyrighted by the Informing Science Institute. Permission to make digital or paper copy of part or all of these works for personal or classroom use is granted without fee provided that the copies are not made or distributed for profit or commercial advantage AND that copies 1) bear this notice in full and 2) give the full citation on the first page. It is permissible to abstract these works so long as credit is given. To copy in all other cases or to republish or to post on a server or to redistribute to lists requires specific permission and payment of a fee. Contact Publisher@InformingScience.org to request redistribution permission. 2009). Through the exchange of information, members of social networking communities work together to achieve better products and services (Silver, 2009) in a manner that puts power in the hands of the consumer who becomes an advocate and voice for a brand (Coulton, 2011).

One-half of US consumers surveyed in a national study reported that they had 
made a purchase based on information that they gathered through about a brand or product via social media. Further, the majority of respondents $(>75 \%)$ reported that recommendations from peers are valuable, credible, and likely to influence their purchasing decisions (DEI Worldwide, 2008). As such, people today look to peer community members in order to find out the truth about products and services, opportunity pricing, vendor after sale support, preferred models, as well as the overall customer experience (Silver, 2009).

Li and Bernoff (2008) used proprietary data and survey research, finding that prepared organizations can reap significant financial benefits in product development, marketing, PR, sales, and customer retention through the use of social media. Additionally, research that has examined believability and impact has found that consumers give greater credence to the opinion of peers above almost any other source (Warwick, 2011, Coulton, 2011, Borrud, 2011, Bazaarvoice, 2012) with peer opinions having significantly greater salience than brand generated messages (Coulton, 2011).

Marketers are no longer the solitary authors of the brand story, but rather, the formerly passive listener is now an active participant in the storytelling and creation process. Sing and Sonnenberg explain that "brand owners do not tell brand stories alone but co-create brand performances in collaboration with the consumers" (2012, p. 189). As a result, products, and services are now social objects that can be examined, discussed, and shared among members of peer networks (Metz, 2011).

Alvin Toffler (1980) introduced the concept of the proactive consumer known as the prosumer in his book The Third Wave to describe common consumers who were predicted to become active so as to influence the design and delivery of goods and services. Social media has brought Toffler's vision to reality by engendering the birth of the social customer, the embodiment of the prosumer, who uses social networking sites as vital information resources for the sharing and consumption of product and brand information (Silver, 2009). As social networking expands prosumption, there a number of implications to the American capitalistic economy (Ritzer, Dean, and Jurgenson, 2012), that Conner (2011) explains tap into "existing predilections for commodity-focused forms of self-realization (p. 309)."

The July 2011 issue of the Prosumer Report extoled that the growth of social media usage has created the ideal conditions to support the growth and expansion of prosumerism. Noting the evolving nature of prosumers, the report identified five types of prosumers: Utilitarians, Entertainers, Advocates, Co-Creators, and Competitors (Havas World Wide, 2011).

Arvidsson and Colleoni (2012) refer to social media services as "prosumer platforms", explaining that they have the capacity to initiate and sustain affective relations, and value realization through "informational capitalism" (p. 135). This informational capitalism has been measured by Bernoff, Cooperstein, Lussant, and Munchbach (2011), who found that consumers generated more than 500 billion impressions about products and services in annually.

The computer maker Dell has embraced the prosumer movement and has been heralded as an exemplar for the effective use of social media in the support of customer relationship management. Through their IdeaStorm program, Dell has created a social community platform that integrates customer service delivered by actual Dell representatives, queries and input from Dell executives, customer engagement in brainstorming sessions regarding product development and improvement, and rewards for superstar contributors (Israel, 2012). Even, the idea for IdeaStorm emerged through a suggestion from a consumer.

In the book, Groundswell: Winning in a World Transformed By Social Networking, (Li and Bernoff, 2008) introduce six categories of consumers who are using social media. The individuals 
labeled as "creators" by Li and Bernoff closely resemble the prosumers introduced by Toffler (1980):

- Creators: Those who create content, perspective and opinions

- Critics: Those who comment/rate/review

- Collectors: Those who aggregate information to make decisions

- Joiners: Those who simply maintain a presence on social networking sites

- Spectators: Those who read, watch and listen - but take no action

- In-actives: Those who do not participate at all

A study by Trusov, Bucklin, and Pauwels (2009), examined the impact of a marketing campaign conducted via a social networking site comparing the results to those of traditional marketing efforts. Using a vector autoregressive approach, they found that the use of social networking results in substantially longer carryover effects than traditional marketing activities with higher rates of action and response elasticity.

Network member composition and the impact of participant diversity have been explored. Following, a content analysis of customers' contributions in a social network focused on the generation of new product ideas for Starbucks Sigala (2012) found that the broader the diversity of customers sharing experiences the more influence was wielded by the group.

Wang, Yu, and Wei (2012) examined the issue of peer conformity verse product uniqueness. After collecting survey data from 292 participants who engaged in peer communications about products through social media they found that online consumer socialization through peer to peer communications impacts purchasing decisions directly by influencing participants to conform with peers and indirectly by reinforcing product involvement. They concluded that group-level identification and individual-level tie strength had a significant impact of the effectiveness on word of mouth advertising spread through peer communications while consumer's need for uniqueness had only a moderate effect on product attitude. Similarly, after investigating the impact of tie strength, endorser expertise, and product type Chang, Chen, and Tan (2012) found that for hedonistic products, strong-tie endorsers were more effective than weak-tie endorsers in influencing purchase intention. On the other hand, for utilitarian products, high-expertise endorsers were more effective than low-expertise endorsers. Finally, a study of 160 individuals invited to participate in a new online community, found that individuals who believed that they would form opinions interdependent with their co-participants were more influenced by electronic word of mouth messages than individuals who considered themselves independent from the group (Lee, Kim, and Kim, 2012).

Diffusion of Innovation Theory considers how innovation is communicated through social networks, which is impacted by norms for diffusion, the type of innovation, the impact of the innovation, and the roles and views of opinion leaders and change agents (Rogers, 1962). Contemporary social networking services are expanding the diffusion of new ideas and are serving as mechanisms for change agents and opinion leaders. Today's change agents are individuals who are able to successfully amass large numbers of "friends" or "followers" in social networking systems and who have a particular talent for launching and promoting new sub-networks by fostering introductions and connections between people. These individuals are able to shape trends, norms, and opinions and can serve as strong connectors between nodes (Reid and Gray, 2007).

Following an examination of SNS users in the Netherlands, researchers found that a minority of SNSs users actively engage in marketing-related activities such as commenting on advertisements or gathering information on brands or products. Rather, they concluded that the majority of SNS users use social media platforms as a communication channel (Lorenzo-Romero, AlarconDelAmo, and Constantindes, 2012). This contradicts a 2010 report (Patrick, Blau, Foong, and Lee) that found that $74 \%$ of consumers actively use social networks to guide purchase decisions. 
Customer relationship management (CRM) is a strategy that cuts across the fields of marketing, customer service, and management, which involves the implementation of strategies that help to attract new clients, build loyalty with existing clients, and increase customer engagement (Buttle, 2012; Amos and Emerson, 2012). The use of social media technologies in CRM activities is known as Social Customer Relationship Management (SCRM), which is predicted to become a transformative phenomenon in the field of marketing (Faase, Helms, and Spruit, 2011).

Examining the impact of social media on customer relationship management, Faase, Helms, and Spruit (2011) found that blogs, media sharing services, and social networking sites add value to all domains of customer relationship management by introducing more two way communication exchanges into the CRM process. Further, they explain that SCRM broadens customer knowledge, perceived value, satisfaction, and interaction.

Some ways in which social networking sites have been shown to expand customer relationship management initiatives are by allowing organizations to have a clearer sense of customer preferences, sentiment, and opinions; engaging customers in more personalized experiences; and use of a customer's trusted peer networks to expand the consumer base (Dorsey, 2012). Additionally, a study of 120 participants (Behravan, and Rahman, 2012) that examined whether online CRM efforts increased customer loyalty found a strong correlation between social CRM and customer retention.

Seventy-nine percent of the 100 largest Fortune 500 corporations are giving credance to the use of social media as a significant channel for marketing communications and customer service (Binhammer and Wilson, 2011). As a result, marketing and promotional activities occurring via social media are lowering cost and expanding reach (Papasolmou and Melanthiou, 2012) while placing the consumer at the center of the marketing process (Thackery, Neger, and Keller, 2012). Across the United States, brands are responding to the changing customer with $94 \%$ of the brand managers questioned in an examination of 3,800 companies reporting that they have added social media into their marketing mix with $83 \%$ saying that it is a strategic imperative for their business (Selzner, 2012). Additionally, 58\% of respondents reported that social media usage has improved sales (Selzner, 2012).

With more than 1.5 billion people across the globe using social networking services and more than 1 in five online hours spent on social networks, McKinsey Global Institute (2012) estimates that in the near future up to one-third of consumer spending could be influenced by social interactions. This equates to more than $\$ 500$ billion in sales annually as companies explore the potential of the $80 \%$ of the world's online population that uses social networks on a regular basis.

\section{Methodology}

A pilot instrument was developed using the online survey tool Zoomerang and disseminated in May of 2010. It was distributed to 386 individuals via an email sent through the Zoomerang system; additionally 200 individuals were also sent a link to the survey via Facebook. The survey was completed by 258 persons representing a response rate of $44 \%$. Following completion of the survey, respondents were given the opportunity to comment on the instrument. Additionally, a panel of experts was formed to review and assist in the validation of the instrument. The expert panel included the editor and chief of a top ranked academic journal, a national brand manager, the vice president of a large media research company, two distinguished marketing professors, and a sociologist. The panel was charged with examining the effectiveness of the target/method match, question design, participant population, delivery methodology, and by identifying possible semantic issues. Based on the results of the pilot study, and feedback from the reviewers, an amended instrument was developed. 
The revised instrument was launched in late 2011 and data was collected during a seven month period. The potential respondent pool included business executives and managers, marketing executives, marketing and management senior standing undergraduate and graduate students, retired professionals, and university business faculty. An email was generated that included a link to the survey. The email was sent via several professional listservs, that had previously been identified as appropriate by the expert panel, inviting both social networking users and non-users to participate. Finally, a paid advertising campaign was also placed through Facebook for a one month period targeted specifically to individuals on record with Facebook as being listed as management or marketing professionals.

The survey was comprised of a combination of Likert scaled, dichotomous multiple choice, and ranking questions. Quantifiable questions were examined based on response percentages, means (where applicable), mode, and standard deviation. The opinions of social networking users and non-users were compared where applicable. Additionally, Anovas, and Chi Square Tests, were performed for select questions.

While a number of considerations were explored, several hypotheses were developed and tested. The hypotheses represent different areas which have been explored to varying degrees within the literature.

- Hypothesis ${ }_{1}$ : Social networking site users promote products and services

- Hypothesis ${ }_{2}$ : Social networking sites can support customer relationship management (CRM).

- Hypothesis ${ }_{3}$ : Word of mouth messages are the most effective form of social marketing.

The hypotheses under consideration represent different areas that have been explored to varying degrees within the literature. Hypothesis 1 has been explored by Warwick (2011), Coulton (2011), Silver (2009), Connor, 2011, Metz (2011), Arividsson and Colleoni (2012), and Li and Bernoff (2008). Hypothesis 2 has been explored by Faase, Helms, and Spruit, 2011; Buttle (2012); and Behravan, and Rahman (2012). Finally, hypothesis 3 has been examined by Borrud (2011) and Coulton (2011).

In addition to the survey findings, results of the paid Facebook advertising campaign were explored and the results reported.

\section{Results and Discussion}

There were 1,078 visits to the survey with 912 completed surveys. Fifty-four percent of the respondents were female, $33 \%$ of the respondents were between 20 and 24 years of age, $19 \%$ were between 25 and 31 years of age, $25 \%$ were between 32 and 44 years of age, and $22 \%$ were $>45$. Participant composition by age is depicted in Figure 1. 


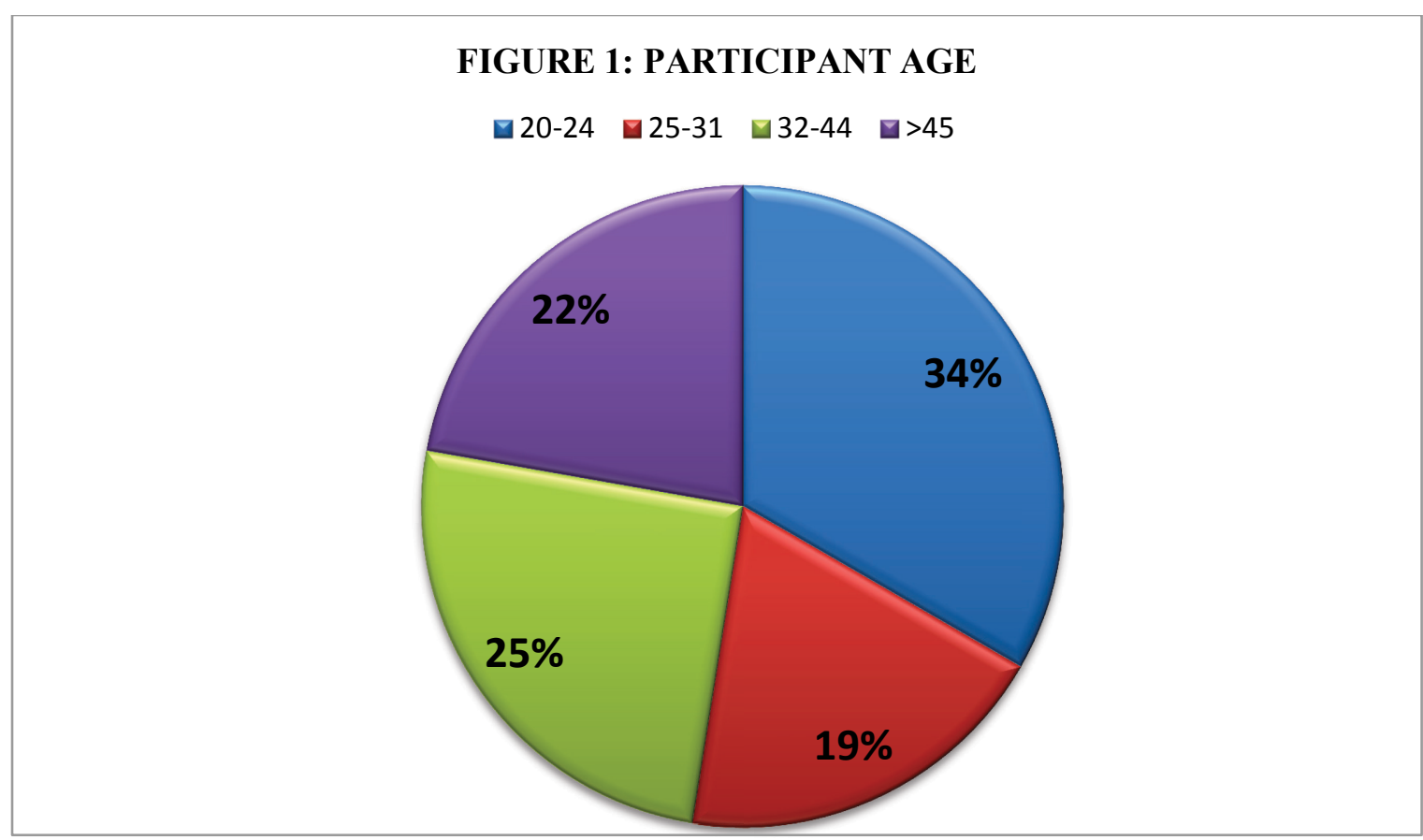

Figure 1. Participant composition by age.

Eighty-six percent of the respondents said that they have a page on Facebook, MySpace, or another social networking site, a statistic that is slightly higher than what was reported by Smith (2011) but consistent with estimates made by the McKinsey Global Institute (2012).

\section{Social Networking Site Users Promote Products and Services via Word of Mouth Advertising}

A series of questions explored whether social media messages impact purchasing decisions as well as whether social media participants are actively promoting products via word of mouth messaging. According to the findings, the majority of social networking site users surveyed $(79 \%)$ reported that they have made a purchase decision based on the recommendations and/or reviews friends have shared via a social networking service. These findings are greater than what was reported by DEI WorldWide (2008) $1 / 2$ of whose participants reported having made a purchase decision based on information gathered via social media but consistent with the $74 \%$ reported by (Patrick, Blau, Foong, and Lee, 2010).

When it came to the promotion of products, most social media users $(73 \%)$ reported that they have become a fan or follower of products or companies they like on social networking sites with $62 \%$ reporting that they regularly recommend products, brands, or companies to friends via social media. Finally, $66 \%$ of respondents reported that they have submitted a product review online. These findings are presented in Table 1 and serve as support for Hypothesis 1 "Social networking site users promote products and services" and are consistent with what has been reported in the literature (Warwick, 2011; Coulton, 2011, Silver, 2009, Connor, 2011, Metz, 2011, Arividsson and Colleoni, 2012, and Bazaarvoice, 2012). 
TABLE 1: ONLINE BRAND INTERACTION AND WORD OF MOUTH EXCHANGES

\begin{tabular}{|l|l|l|} 
& \multicolumn{2}{l|}{$\begin{array}{l}\text { SNS Users } \\
\text { (\%) }\end{array}$} \\
\hline Question & Yes & No \\
\hline $\begin{array}{l}\text { I have made a purchase decision based on the recommendations and reviews my friends } \\
\text { have shared via a social networking service. }\end{array}$ & 79 & 21 \\
\hline $\begin{array}{l}\text { I follow or have become a fan of products or companies I like } \\
\text { I regularly recommend products, brands, or companies to friends via Facebook or another } \\
\text { social networking site }\end{array}$ & 73 & 27 \\
\hline I have posted or submitted product reviews online. & 66 & 38 \\
\hline
\end{tabular}

\section{Social Networking Sites Can Support Customer Relationship Management (CRM)}

Most respondents, $51 \%$ of social networking site (SNS) non-users and $76 \%$ of users agreed that social networking site usage is an important corporate strategy. These findings are displayed in Table 2 and are consistent with the literature that finds that social networking site usage is a strategic imperative for contemporary companies (Buttle, 2012; Selzner, 2012).

\section{TABLE 2: PERCEPTIONS OF THE IMPORTANCE OF SOCIAL MEDIA AS A CORPO- RATE STRATEGY COMPARISON OF SNS USERS AND NON USERS}

\begin{tabular}{|l|l|l|l|l|l|l|}
\hline & \multicolumn{2}{|l|}{$\begin{array}{l}\text { All Participants } \\
(\%)\end{array}$} & \multicolumn{2}{l|}{ SNS Users (\%) } & \multicolumn{2}{l|}{$\begin{array}{l}\text { SNS NonUs- } \\
\text { ers (\%) }\end{array}$} \\
\hline Question & Yes & No & Yes & No & Yes & No \\
\hline $\begin{array}{l}\text { Social networking participation has become a } \\
\text { strategic imperative for companies }\end{array}$ & 76 & 24 & 81 & 19 & 51 & 49 \\
\hline
\end{tabular}

Further, $81 \%$ of currently the employed participants reported that their employeers maintain a social media presence (blog, Facebook or MySpace Page, Twitter Account,etcetera); however, most companies $(<16 \%)$ do not make available social media management or social marketing training. As such, most participants $(61 \%)$ agreed that "corporate executives are not adequately informed with strategies for how to effectively use social media to support marketing and brand management efforts." These findings are reported in Table 3 and are consistent with what has been reported by Williams (2012) who found that less than 1 in 5 companies offer some type of social media training

\section{TABLE 3 : PERCEPTIONS OF MANAGEMENT AND MARKETING PROFESSIONALS}

\begin{tabular}{|l|l|l|l|}
\hline & \multicolumn{3}{|c|}{ (\%) } \\
\hline Question & Yes (\%) & No (\%) & $\begin{array}{l}\text { Unsure/No } \\
\text { Idea (\%) }\end{array}$ \\
\hline $\begin{array}{l}\text { My company maintains a social media presence (blog, Facebook or } \\
\text { MySpace Page, Twitter Account, etcetera) }\end{array}$ & 81 & 19 & $-\mathrm{N}-$ \\
\hline $\begin{array}{l}\text { My company offers or makes available social media, social busi- } \\
\text { ness, and/or social marketing training to employees }\end{array}$ & 16 & 72 & 22 \\
\hline $\begin{array}{l}\text { Corporate executives are not adequately informed with strategies for } \\
\text { how to effectively use social media to support marketing and brand } \\
\text { management efforts }\end{array}$ & 61 & 24 & 15 \\
\hline
\end{tabular}


Due to the participant population, customer relationship management should have been a familiar concept to survey respondents; however, in order to insure question validity customer relationship management was explained to participants. According to the findings, both SNS users and nonusers responded that social media can support CRM efforts. These results are expressed in Table 4 and are consistent with what has been reported by Dorsey (2012), Amos and Emerson (2013), Behravan and Rahman (2012), Buttle (2012), Brazier (2012), Faase, Helms, and Spruit, (2011), and Metz (2011). Additionally, these findings support for Hypothesis 2 "Social networking sites support customer relationship management (CRM)."

\section{TABLE 4: RESPONSES TO STATEMENT SOCIAL MEDIA CAN SUPPORT CRM EF- FORTS COMPARISON OF SNS USERS AND NON USERS}

\begin{tabular}{|l|l|l|l|l|l|l|}
\hline & \multicolumn{2}{|l|}{$\begin{array}{l}\text { All Participants } \\
\text { (\%) }\end{array}$} & \multicolumn{2}{l|}{ SNS Users (\%) } & \multicolumn{2}{l|}{$\begin{array}{l}\text { SNS NonUs- } \\
\text { ers (\%) }\end{array}$} \\
\hline Question & Yes & No & Yes & No & Yes & No \\
\hline Social media can support CRM efforts & 81 & 19 & 85 & 15 & 60 & 40 \\
\hline
\end{tabular}

The impact of social networking on CRM was further explored with a five-point Likert scaled question that examined whether social networking site use is effective for creating brand focused communities. According to the findings SNS users consider social media an important tool in the branding/community building process with SNS non-users largely undecided. The overall mean across participant groups was considered and found to be a 3.61/5.0. The mean for SNS users was a 3.70/5.0 and the mean for non SNS users was a 3.08/5.0. The findings from this question are consistent with what has been reported by in the literature and also provide support for Hypothesis 2 .

Additionally, an Anova was conducted that looked at whether there was a significant difference in the perceptions of participants with a social media presence verse those without. With a $p$ value set to .05 , the results were .83 , indicating a lack of significance. Table 5 presents the results of the data analysis.

\begin{tabular}{|c|c|c|c|c|}
\hline \multicolumn{5}{|c|}{$\begin{array}{l}\text { TABLE 5: PERCEPTIONS OF THE USE OF SOCIAL MEDIA IN BRANDING- } \\
\text { RESPONSE TO THE STATEMENT "SOCIAL NETWORKING IS GOOD FOR COM- } \\
\text { MUNITY BUILDING WITH CUSTOMERS." }\end{array}$} \\
\hline & \%Users & \multicolumn{2}{|c|}{ \%Nonusers } & Descriptives \\
\hline $\begin{array}{l}1 \text { - Strongly Disa- } \\
\text { gree }\end{array}$ & $4 \%$ & \multicolumn{2}{|l|}{$6 \%$} & Mean Users 3.70 \\
\hline 2 - Disagree & $8 \%$ & \multicolumn{2}{|l|}{$18 \%$} & Mean Non Users 3.08 \\
\hline 3 - Neutral & $20 \%$ & \multicolumn{2}{|l|}{$40 \%$} & Mode Users 4 \\
\hline 4 - Agree & $48 \%$ & \multicolumn{2}{|l|}{$36 \%$} & Mode Non Users 3 \\
\hline 5 - Strongly Agree & $19 \%$ & \multicolumn{2}{|l|}{$1 \%$} & \\
\hline Total & $100 \%$ & \multicolumn{2}{|l|}{$100 \%$} & \\
\hline Overall Mean & $\begin{array}{l}\text { ANOVA } \\
\text { (a) 95\% (.05) }\end{array}$ & $\begin{array}{l}\text { Standard } \\
\text { Deviation }\end{array}$ & $\begin{array}{l}\text { Standard } \\
\text { Error }\end{array}$ & Confidence Interval @95\% \\
\hline 3.61 & $\begin{array}{l}\mathbf{P}=\mathbf{8 3}(\mathrm{P}>.05 \text { insignifi- } \\
\text { cant })\end{array}$ & 1.03 & .03 & [3.54 - 3.67] \\
\hline
\end{tabular}




\section{Word of Mouth Messages are the Most Effective Form of Social Marketing}

An anecdotal exploration into this topic was conducted through a Facebook campaign. First, an advertisement was created that urged management and marketing professionals to provide crucial insight into the current and future role of social media in professional practice. The campaign was targeted specifically to management and/or marketing executives where a standard homepage advertisement was placed on their Facebook homepage/timeline. The advertisement generated 530,974 targeted impressions with 26,273 clicks representing a click rate of around 5\% (.04948). From the 26,273 clicks there were 782 "likes" representing a "like" rate of approximately $3 \%$ (.02976) among individuals who clicked on the homepage advertisement. The 782 "likes" resulted in the generation of 6,665 social impressions (impressions that included that names of friends that liked the advertisement) representing an increase of $8.52 \%$ from the number of initial "likes". The total number of surveys completed as a result of the advertising campaign was 281 out of which 203 were individuals responding from the standard homepage advertisement at a rate less than $1 / 2$ of $1 \%(.000382)$ and 78 individuals who responded to a social impression (hybrid of paid and newsfeed stories sent to friends of users which reference friends who are fans) representing a response rate to the social impression of 1\% (.01177). In addition to the Facebook marketing campaign, there were 600 invites (word of mouth marketing messages) generated to the survey and sent to management and marketing professionals sent using the Facebook messaging tool. The personalized invitations contained an appeal from the researcher with an explanation of the academic nature of the study. The personal invitations resulted in 196 completed surveys or a response rate of $32 \%$. Please note, the remaining 465 completed surveys were the result of postings on various professional listservs for management and marketing professionals, faculty and/or senior or graduate standing students, where the response rate is unknown. While these findings are not a valid measure of the effectiveness of social media marketing, they do provide interesting anecdotal information, that may suggest that message type, perceived personalization, and group identification impact the success rate of social marketing efforts, similar to what has been reported by Wang, Yu, and Wei (2012).

A more scientific examination of message type was measured in the survey instrument where participant perceptions of different social marketing strategies were examined. Marketing messages conveyed via social media outlets was divided into three categories for the purpose of this study: Standard Homepage Ads (paid messages with an option to engage with the brand), Social Impressions (hybrid of paid and newsfeed stories sent to friends of users which reference friends who are fans of the brand), and Organic Impressions (word of mouth unpaid earned media resulting from a friends suggestion to become an, an initiated search, user generated content, or a newsfeed posted by a friend). Social networking site users were asked to consider the three social marketing presented and asked to rank them from most to least effective with 1 representing most effective. According to the findings: organic impressions/word of mouth advertising was considered the most effective with standard homepage advertisements considered to be the least effective form of marketing conducted via the use of social media outlets. These results, which are represented in Table 4 and Figure 2, are consistent with what has been reported by Trusov, Bucklin, and Pauwels (2009), Coulton (2011), Borrud (2011), and Wang, Yu, and Wei (2012); however, a Chi Square Test was conducted in order to test hypothesis 3: "Word of mouth is the most effective form of social marketing". With a significance level of .05 used and a result of .06009 the Chi Square results were not able to support the hypothesis as a $94 \%$ probability of truth was supported. 
TABLE 4: EFFECTIVENESS OF DIFFERENT SOCIAL MARKETING MESSAGES

\begin{tabular}{|l|l|l|l|l|l|}
\hline $\begin{array}{l}\text { 1 EQUALED MOST EFFECTIVE } \\
\text { AND 3 EQUALED LEAST EFFEC- } \\
\text { TIVE }\end{array}$ & Mean & Mode & $\begin{array}{l}\text { Standard } \\
\text { Deviation }\end{array}$ & $\begin{array}{l}\text { Standard } \\
\text { Error }\end{array}$ & $\begin{array}{l}\text { Confidence In- } \\
\text { terval } \\
\text { a 95\% }\end{array}$ \\
\hline $\begin{array}{l}\text { Standard homepage ads: Paid media, } \\
\text { which contain ad \& an option for users to } \\
\text { engage with the brand (e.g., "Become a } \\
\text { Fan"). }\end{array}$ & 2.25 & 3 & 0.86 & 0.04 & {$[2.18-2.32]$} \\
\hline $\begin{array}{l}\text { Homepage ads w/ social context: Hybrid } \\
\text { of paid and newsfeed stories sent to } \\
\text { friends of users which include the names } \\
\text { of a user's friends who are already fans } \\
\text { of the brand. }\end{array}$ & 1.91 & 2 & 0.64 & 0.03 & {$[1.86-1.96]$} \\
\hline $\begin{array}{l}\text { Organic impressions/WOM: Unpaid } \\
\text { earned media: received as a result of a } \\
\text { friend's suggestion to become a fan, an } \\
\text { initiated search, a newsfeed posted by a } \\
\text { friend that contains a product recom- } \\
\text { mendation, or a friends post on their } \\
\text { page e.g. word of mouth }\end{array}$ & 1.78 & 1 & 0.81 & 0.03 & {$[1.77-1.88]$} \\
\cline { 2 - 6 } & Chi Square @95\% .06009 & & & \\
\hline
\end{tabular}

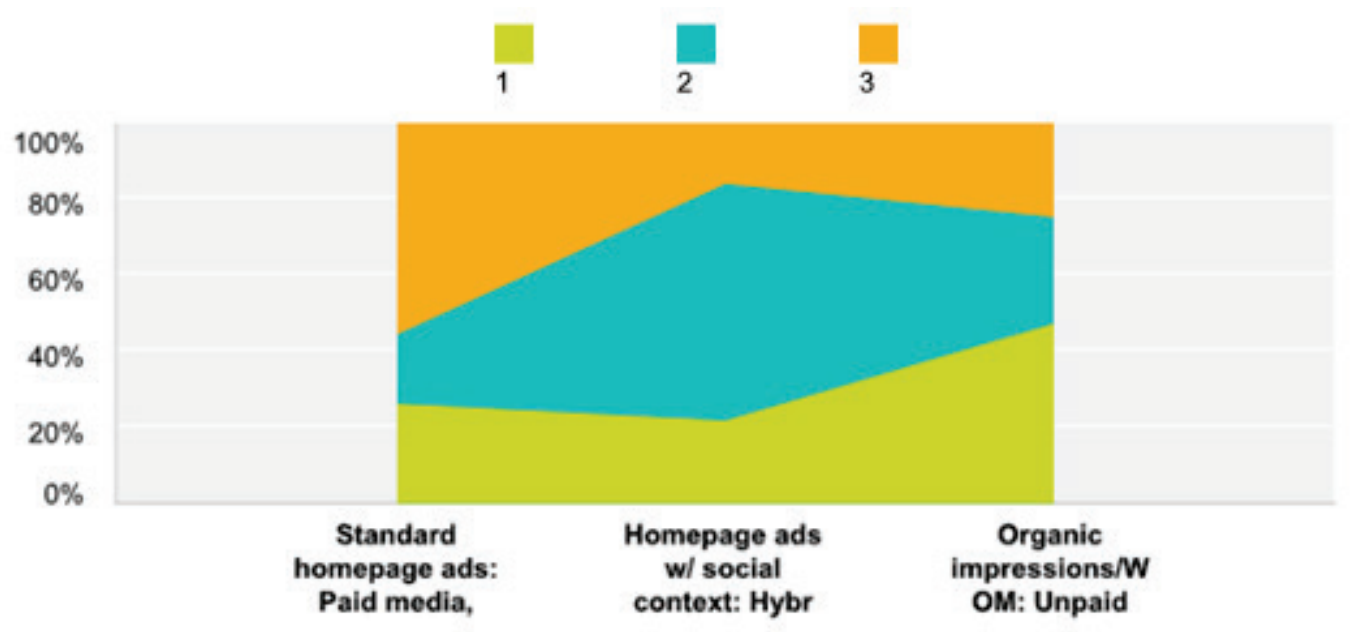

Figure 2: Rank of facebook marketing messages with 1 being most effective and 3 being least effective

Message salience was examined through a series of five-point Likert-scaled questions that asked participants to rank different types of messages from very influential (5) to totally irrelevant (1). According to the participants positive or negative reviews authored and posted by friends or family members are the most influential. Customer reviews written on a retailer's website and product recommendations in the form of "likes" shared by friends were also considered influential. Information posted by companies either on their website or through a newsfeed was ranked as less influential. These findings are shown in Table 5 and are consistent with what has been reported in the literature, where the consensus is that consumers give the greatest credence to the opinion of peers above almost any other source (Coulton, 2011) the value of which is recognized by management and marketing professionals as companies attempt to harness the wisdom of the masses (Patrick, Blau, Foong, and Lee, 2010; Bernoff, Cooperstein, Lussant, and Munchbach, 2011; 
Bazzaarvoice, 2012). Further, the findings support Hypothesis 3 "Word of mouth messages are the most effective form of social marketing."

\section{TABLE 5: MESSAGE SALIENCE}

\begin{tabular}{|l|r|r|r|r|}
\hline $\begin{array}{l}\text { Please rank each of the from very influential } \\
\text { (5) to totally irrelevant (1) }\end{array}$ & Mean & Mode & $\begin{array}{r}\text { Standard } \\
\text { Deviation }\end{array}$ & $\begin{array}{r}\text { Confidence } \\
\text { Interval @ } \\
95 \%\end{array}$ \\
\hline $\begin{array}{l}\text { A positive or negative review authored, and } \\
\text { posted, by a friend or family member. }\end{array}$ & 4.33 & 4 & 0.76 & {$[4.18-4.45]$} \\
\hline $\begin{array}{l}\text { Customer reviews written on a retailers website } \\
\text { Informal product recommendations in the form } \\
\text { of "likes" shared a friends }\end{array}$ & 3.44 & 4 & 0.61 & {$[3.33-3.55]$} \\
\hline Information on the company website. & 2.35 & 3 & 0.59 & {$[3.24-3.45]$} \\
\hline $\begin{array}{l}\text { Newsfeeds posted by company regarding their } \\
\text { products and services }\end{array}$ & 2.83 & 3 & 0.78 & {$[2.69-2.97]$} \\
\hline
\end{tabular}

\section{Study Limitations}

As with any primary research, there were a number of limitations that may impact the study; accordingly, caution is necessary when interpreting the findings. The most prominent limitation of the study is the distribution of survey invites. Survey invites were distributed via email, through a number of professional listservs and other distribution lists, posted on Facebook, as well as promoted through a paid social media marketing campaign. This use of technology in the promotion and distribution of survey invites to potential respondents may have resulted in a self-selection of a higher percentage of technologically savvy participants.

\section{Summary and Concluding Thoughts}

It is widely recognized, both among academicians and professionals, that consumers are evolving and this metamorphosis is being largely engendered by social media. This study found participants exhibiting prosumer behaviors through the use of social media as a means to share comments, perspectives, and opinions about goods and services. As such, mediated messages conveyed through SNS are influencing purchase decisions with word of mouth messages paramount in consequence and ability to impel action.

The management and marketing professionals who participated in this study reported that the integration of social media into business practices is a strategic imperative for contemporary companies that can, if used expeditiously, support customer relationship management efforts. At the same time, these efforts may be hindered as corporate leadership continues to be ill informed about the effective strategies for the use of social media to support marketing and brand management, which is further exacerbated by the dearth of available training opportunities.

This study is significant because it takes a multi-methodological approach and uses a large nationwide base of participants who were non-opportunistic. It ties together a number of concepts into a single study that have previously only been explored in isolation within the literature. Finally, a validated instrument was employed.

As social networking continues to grow unabated, it is posed to redefine how we inform clients, whether they are students, customers, constituents, or the like. Timely and continued research on the impact and potential of social networking in business practices is crucial to the discipline. The 
primary aim of the research presented in this paper is to engender discussion and help to shape and encourage additional research studies on the impact of social networking on contemporary business practices.

\section{References}

Amos, J., \& Emerson, B. J. (2013). The Taste D-Lite Way: Social marketing lessons for building loyalty and a brand customers crave. New York, N.Y: McGraw Hill.

Arvidsson, A., \& Colleoni, E. (2012). Value in informational capitalism and on the internet. Information Society, 28(3), 135-150. doi:10.1080/01972243.2012.669449

Bazaarvoice. (2012). Social trends report 2012. Retrieved 2/13/13 from: http://www.bazaarvoice.com/social-trends-report-2012

Behravan, N., \& Rahman, M. (2012). Customer relationship management constructs under social networks towards customers' retention. Australian Journal of Basic and Applied Sciences, 6(7), 271-282.

Bernoff, J., Cooperstein, D., Lussant, M., \& Munchbach, C. (2011). Competitive strategy in the age of the customer. Forrester, Inc.

Binhammer, R., \& Wilson, A. (2011). Lay the groundwork for future success: Where to embed social media. Proceedings of the $2^{\text {nd }}$ Annual Corporate Social Media Summit. June 21-22, 2011. New York, NY.

Borrud, P. (2011, March). The wisdom of friends. 2011 digital survival guide. Niche Publishing, Melbourne.

Buttle, F. (2012). Customer relationship management (2nd Ed). New York, N.Y: Routledge.

Chang, K. T., Chen, W., \& Tan, B. Y. (2012). Advertising effectiveness in social networking sites: Social ties, expertise, and product type. IEEE Transactions on Engineering Management, 59(4), 634-643.

Comor, E. (2011). Contextualizing and critiquing the fantastic prosumer: Power, alienation and hegemony. Critical Sociology (Sage Publications, Ltd.), 37(3), 309-327. doi:10.1177/0896920510378767

Coulton, M. (2011). Consumer word of mouth and the virtual community. Proceedings of the Online Conference on Networks and Communities. Retrieved 7/212 from http://networkconference.netstudies.org/2011/04/consumer-word-of-mouth-and-the-virtualcommunity/

DEI WorldWide (2008). Engaging consumers online: The impact of social media on purchasing behavior. 1(1). DEI WorldWide. United States.

Dorsey, P. (2012). Social media is not social CRM, but it can be with these five steps. Marketing Profs Dot Com. Retrieved: 7/23/2012 from http://www.marketingprofs.com/articles/2012/7627/social-media-isnot-social-crm-but-it-can-be-with-these-five-steps\#ixzzl tqfkA3hL

Faase, R., Helms, R., \& Spruit, M. (2011). Web 2.0 in the CRM domain: Defining social CRM. Journal of Electronic Customer Relationship Management, 5(1), 1-22.

Havas World Wide. (2011, July). The spread of internet usage and social media habits has created perfect conditions for the next phase of Prosumerism. The Prosumer Report. 12(7).

Israel, S. (2012). Dell modernizes IdeaStorm. Forbes. Retrieved 2/13/13 from: http://www.forbes.com/sites/shelisrael/2012/03/27/dell-modernizes-ideastorm/

Lorenzo-Romero, C., Alarcón-Del0Amo, M., \& Constantindes, E. (2012). Segmentation of users of social networking websites. Social Behavior \& Personality: An International Journal, 40(3), 401-414. doi:10.2224/sbp.2012.40.3.401

Lee, D., Kim, H., \& Kim, J. (2012). The role of self-constual in consumers electronic word of mouth (eWOM) in social networking sites: A social cognitive approach. Computers in Human Behavior, 28(3), 1054-1062. 
Li, C., \& Bernoff, J. (2008). Groundswell: Winning in a world transformed by social technologies. Boston, MA: Harvard Business Press.

McKinsey Global Institute. (2012). Social economy: Unlocking value and productivity through social technologies. Retrieved 2/12/2013 from http://www.slideshare.net/hrtecheurope/mckinsey-report-socialeconomy

Metz, A. (2011). The social customer: How brands can use social CRM to acquire, monetize, and retain fans, friends, and followers. New York, N.Y: McGraw Hill.

Papasolomou, I., \& Melanthiou, Y. (2012). Social media: Marketing public relations' new best friend. Journal of Promotion Management, 18(3), 319-328. doi:10.1080/10496491.2012.696458

Patrick, C., Blau, B., Foong, K., \& Lee, C.J. (2010). User survey analysis: Trends in consumers' use of social media. Gartner, Inc. Dataquest Market Insights: Carrier Operations \& Strategies Worldwide. ID Number: G00213348

Reid, M., \& Gray, C. (2007). Online social networks. Virtual Communities, Enterprises, and Information Professionals, 15(7). Retrieved 3/4/2010 from http://www.infotoday.com/searcher/jul07/Reid_Grey.shtml

Rogers, E. (1962). Diffusion of innovations. Glencoe: Free Press.

Selzner, M. (2012). 2012 Social media marketing industry report: How marketers are using social media to grow their business. Social Media Examiner. Retrieved 5/2/2012 from: http://www.socialmediaexaminer.com/social-media-marketing-industry-report-2012/

Silver, D. (2009). The social networking business plan. Hoboken, N.J: John Wiley and Sons.

Sigala, M. (2012). Social networks and customer involvement in new service development (NSD): The case of www.mystarbucksidea.com. International Journal of Contemporary Hospitality Management. 24(7), 966 - 990.

Singh, S., \& Sonnenburg, S. (2012). Brand performances in social media. Journal of Interactive Marketing, 26(4), 189-197.

Smith, A. (2011). Why Americans use social media. Pew Research Center. Available at http://pewinternet.org/ /media//Files/Reports/2011/Why\%20Americans\%20Use\%20Social\%20Media. $\underline{\mathrm{pdf}}$

Thackery, R., Neiger, B., \& Keller, H. (2012). Integrating social media and social marketing: A four step process. Health Promotion Practice, 13(2), 165-168.

Toffler, A. (1980). The third wave. New York, NY: Bantam Books.

Trusov, M., Bucklin, R., \& Pauwels, K. (2009). Effects of word-of-mouth versus traditional marketing: Findings from an internet social networking site. Journal of Marketing, 73(5). 90-102.

Wang, X., Yu, C., \& Wei, Y. (2012). Social media peer communication and impacts on purchase intentions: A consumer socialization framework. Journal of Interactive Marketing, 26(4), 198-208.

Warwick, D. (2011, March). Agencies, lies and social media. 2011 Digital Survival Guide. 112-114. Niche Publishing, Melbourne.

Williams, J. (2012). Social media: Show us the money: Being 'liked' is fine, but firms want social media results. USA Today. 9/8/2012. 


\section{Biography}

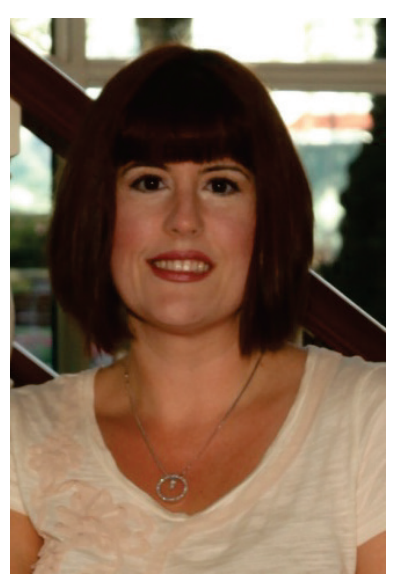

Dr. Nicole A. Buzzetto-More is an Associate Professor, Program Coordinator, and the Assurance of Learning and Assessment Chair in the Department of Business at the University of Maryland Eastern Shore. She is also Director of the Maryland State Department of Education Program Affiliate for Business, Management, and Finance. She received doctorate and masters degrees from Columbia University and earned a post doctorate from Tulane University. She also earned a masters degree from the College of New Rochelle and a bachelor's degree from Marist College. Dr. Buzzetto-More is a frequent invited presenter at conferences across the globe; is on the editorial board of several journals; has authored numerous publications; and has been recognized with awards from the American Distance Education Consortium, Global Digital Business Association, and the Informing Science Institute. Recently, she was named a Fellow of the Informing Science Institute. She published two books in 2007, Principles of Effective Online Teaching and Advanced Principles of Effective ELearning. In 2010 her third book The E-Portfolio Paradigm: Informing, Educating, Assessing, and Managing with E-Portfolios was published by the Informing Science Press. She can be reached at nabuzzetto-more@umes.edu 